\title{
Modellezett vízelöntés talajszerkezetre gyakorolt hatásának komputertomográfiás vizsgálata
}

\author{
${ }^{1}$ GÁL Norbert, ${ }^{2}$ M. TÓTH Tivadar, ${ }^{3}$ FöLdES Tamás és ${ }^{1}$ FARSANG Andrea \\ ${ }^{1}$ SZTE Természeti Földrajzi és Geoinformatikai Tanszék, Szeged \\ ${ }^{2}$ SZTE Ásványtani, Kőzettani és Geokémiai Tanszék, Szeged \\ ${ }^{3}$ Kaposvári Egyetem, Diagnosztikai és Onkoradiológiai Intézet, Kaposvár
}

\section{Bevezetés}

A talaj értéke attól függ, hogy mennyire tud eleget tenni az elvárt multifunkcionalitásának (VÁRALLYAY, 2005). A talaj sokoldalú funkcióival számos mechanikai és hidraulikus stresszhatás áll kölcsönhatásban, melyek közül az intenzív mezőgazdasági művelés, valamint az egyre gyakoribb szélsőséges időjárási helyzetek is korlátozhatják a talaj ökológiai funkcióit (termékenységét, szürö-, pufferoló vagy vízraktározó képességét). A talajfunkciók zavartalan müködéséhez elengedhetetlen a kedvező talajszerkezet, amely porozitásától, pórusméreteloszlásától és tömörödöttségétől függően biztosítja a gyökérzet fejlődését, a levegőzöttséget, a vízbeszivárgást, a tápanyag-visszatartást és az anyagtranszport folyamatokat (CRESTANA \& VAZ, 1998; PIRES et al., 2008; SANDER et al., 2008).

A belvíz a szélsőségesen csapadékos időjárási helyzet egyik következménye, erősíti a hidraulikus stresszhatást, fokozza a talajdegradációt és az erózióérzékenységet (ZINK et al., 2011; GÁL \& FARSANG, 2013). A belvíz azonban nem csak degradációt kiváltó tényező, hanem a talajdegradáció potenciális következménye is, hiszen a belvíz és a talaj között kölcsönös visszacsatolási mechanizmusok, összefüggések figyelhetők meg (GÁL \& FARSANG, 2012) (1. ábra).

A belvízelöntés tartós, akár két-három hónapos vízborítással, majd az azt követő kiszáradással nedvesedési-száradási ciklusként (wetting and drying cycle, WDC) értelmezhető, akként modellezve vizsgálható. Számos tanulmány ellenére sincs egységes álláspont azzal kapcsolatban, hogy az ismétlődő nedvesedés és száradás milyen irányban, illetve milyen ütemben változtatja meg a talaj szerkezeti állapotát. A szerkezetileg leromlott talajok esetében a nedvességtartalom ismétlődő változása elősegíti az aggregátumok képződését, ugyanakkor kérgesedést, cserepesedést válthat ki a taposott feltalajban (RICHARDSON, 1976). Taposás-mentes feltalaj esetében a száradás hatására bekövetkező zsugorodás a talajfelszín cserepesedése nélkül megy végbe, lemezes szerkezetet eredményezve.

Postai cím: GÁL NORBERT, SZTE Természeti Földrajzi és Geoinformatikai Tanszék, 6722 Szeged, Egyetem u. 2-6. E-mail: galnorbert@geo.u-szeged.hu 
HILLEL (2004) ill. RASA és munkatársai (2012) a nedvesedés, a tavaszi hóolvadás vagy a tartós vízborítás hatására bekövetkezett aggregátum-szétesés eredményeként egy diszperz szemcsékből álló, milliméter vastag, tömörödött réteget figyeltek meg a feltalajon, melynek - elsősorban agyag méretü - szemcséi a pórusteret kitöltve tömörödötté teszik a feltalajt.

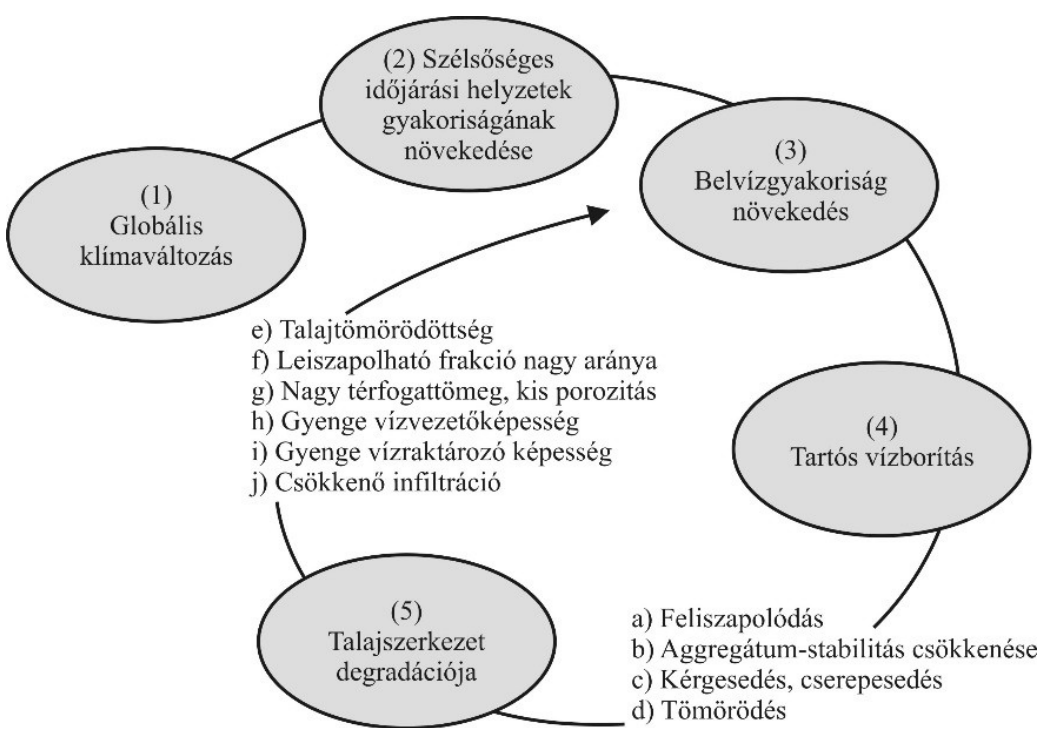

1. ábra

A talaj és a belvízelöntés közötti visszacsatolási rendszer

TISDALL és munkatársai (1978) ill. RAJARAM és ERBACH (1999) már egyszeri WDC után talajtömörödésről (nagyobb penetrációs ellenállásról) és kisebb aggregátum-stabilitásról számoltak be. Ezzel szemben PIRES és munkatársai (2007, 2008, 2010) a talajminták szerkezeti javulását, a térfogattömeg csökkenését tapasztalták, bolygatatlan szerkezetủ minták ismételt WDC kezelése után. A nedvesítés közben a porozitás növekedését mutatták ki a minták duzzadásának, térfogat növekedésének hatására.

A bolygatatlan szerkezetủ talajminták (1-5 mm átméröjü) makropórusainak vizsgálatát az 1980-as évekig gátolta a nem destruktív vizsgálati módszer hiánya. A korábbi, felnagyított talajkeresztmetszet vizsgálatot, vékonycsiszolat készítést, a talajminták gyantával történő kipreparálását egészítette ki később az orvostudományban széleskörüen használt komputertomográfia (CT), mely a szerkezet roncsolása nélkül, milliméter-mikrométer léptékben teszi lehetővé a vizsgált objektum belső sürüségviszonyainak vizsgálatát, modellezését (ANDERSON et al., 1990; PIRES et al., 2010).

A kezdeti CT-s kutatások (Petrovic et al., 1982; HAINSWORTH \& AYLMORE, 1983; CRESTANA et al., 1985) kimutatták a talajminták átlagos térfogattömege, po- 
rozitása, nedvességtartalma és a röntgen-sugárzás sugárgyengülési együtthatója közötti lineáris kapcsolatot.

A komputertomográf segítségével a talaj belső szerkezete leképezhetővé vált több, különböző irányból felvett projekció alapján, kétdimenziós keresztmetszeti képek, szeletek felhasználásával. A kétdimenziós szeletek egymás után rendezésével pedig a talaj belső sürüségviszonyainak háromdimenziós rekonstrukciója is megvalósulhatott.

Napjainkban a komputertomográfiát számos talajszerkezeti vizsgálatban alkalmazzák. LIPIEC és HATANO (2003) ill. PIRES és munkatársai (2003) a talaj közlekedés okozta tömörödését, HAINSWORTH és AYLMORE (1983), LANGMAACK és munkatársai (1999), ill. JÉGOU és munkatársai (2002) pedig a földigiliszták és a gyökerek szerkezetmódosító hatását kutatták. Az eltérö földmüvelési eljárások talajszerkezetre gyakorolt hatását pl. GANTZER és ANDERSON (2002) és PEDROTTI és munkatársai (2005) vizsgálták; míg PIRES és munkatársai $(2005,2008)$ ill. PETH és munkatársai (2010) a hidraulikus stresszhatás okozta talajszerkezeti változásokat és komputertomográfiás vizsgálati eredményeiket publikálták.

Hazai vonatkozásban GYARMATI (2013) a talajoszlopok gázdiffúziójának komputertomográfiás vizsgálatának eredményei, valamint MIKITA (2013) hidro- és mérnökgeológiai képdiagnosztikával kapcsolatos munkássága említendő meg. BARNA és munkatársai (2013) is komputertomográfiás módszerrel vizsgálták a felületaktív anyagok szerves folyadékkal szennyezett talajok szivárgási tényezőjére gyakorolt hatását.

A komputertomográfia földtudományi területeken történő alkalmazása széles körben elterjedt, azonban a talaj - belvíz okozta - ismételt nedvesedésének, száradásának hatását nagyobb térfogatú mintákon modellezve még kevesen kutatták. Célul tüztük ki, hogy a korábbi, vonatkozó szakirodalmi módszerektől eltérően, nagyobb térfogatú, bolygatatlan szerkezetủ talajmintákon vizsgáljuk a belvíz hatását egy eredendően jó vízgazdálkodású talaj szerkezetére (térfogattömegére) három nedvesedési-száradási ciklust modellező kísérletben.

\section{Vizsgálati anyag és módszer}

\section{Mintavétel, talajtani alapvizsgálatok}

Az ismétlődő nedvesedés és száradás szerkezetmódosító hatását és annak mértékét egy belvízzel korábban nem érintett, szerkezetileg nem degradált, jó minőségü csernozjom talaj felső, müvelt $\mathrm{A}_{\mathrm{sz}}$ szintjéből származó mintákon vizsgáltuk. A talajmintákat a Hódmezővásárhelytől DK-i irányban 10 km-re lévő gorzsai paprikatermelö üzem mezőgazdasági művelésbe bevont területén vettük 2012 decemberében. A mintavételi pontban (É: 46²1'42,09", K: 20²6'17,12") négy ismétlésben gyüjtöttünk bolygatatlan talajmintákat (G1-G4).

A vonatkozó szakirodalomban jegyzett, kisebb $\left(50-100 \mathrm{~cm}^{3}\right)$ térfogatú patronos bolygatatlan mintavétel magában hordozza a mintavételi patron falának nagymérvủ 
szerkezetmódosító hatását (PIRES et al., 2004), ezért a talajszerkezet vizsgálatok megfelelő reprezentativitásához 9-10 ezer $\mathrm{cm}^{3}$-es mintákat gyüjtöttünk.

A mintavétel során $40 \mathrm{~cm}$ magasságú, $19 \mathrm{~cm}$ belső átmérỏjü PVC csövet nyomtunk a talajba, körbeásással segítve a cső lefelé haladását, minimalizálva ezzel a bolygatást. A talajoszlopok aljára geotextilt helyeztünk, majd alulról több helyen átfúrt PVC kupakkal zártuk a csövet, hogy a későbbi nedvesítési-száradási ciklusok során az oszlopban lévő víz alul eltávozhasson.

A mintavétel közvetlen környezetéböl $60 \mathrm{~cm}$ mélységig $10 \mathrm{~cm}$-enként bolygatott mintákat is gyüjtöttünk a talajtani alapvizsgálatokhoz.

A talajminták porítását és $2 \mathrm{~mm}$-es szitálását követően meghatároztuk azok kémhatását, összes só-, karbonát- és szerves-anyag tartalmát és fajsúlyát (BuZÁs, 1988; MSz 08-0206-2: 1978; MSz 21470-52: 1983). A mechanikai összetételt 10\%os $\mathrm{H}_{2} \mathrm{O}_{2}$, majd 10\%-os HCl-oldattal történő előkezelést követően Fritsch Analysette 22 készülékkel határoztuk meg három ismétlésben, a mintákat ultrahangos berendezéssel homogenizálva - a KUN és munkatársai (2013) által javasolt módszertan szerint.

A talajminták térfogatát a különböző időpontokban készített CT felvételek alapján határoztuk meg. Osiris 4.19 szoftverrel meghatároztuk a CT szeletek talajt tartalmazó pixeleinek összterületét, majd a szeletek magasság és szélesség értékéböl származtattuk a talajoszlop hengertérfogat értékét. A térfogattömeget és az aktuális nedvességtartalmat a különböző nedvességi állapotú és a $105^{\circ} \mathrm{C}$-on szárított minták tömegmérését követően számítottuk. Az összes porozitást a térfogattömeg és fajsúly értékek ismeretében határoztuk meg.

\section{Nedvesitési-száradási ciklusok (WDC-k) beállitása}

Az ismétlődő belvízelöntést mesterségesen előállított nedvesítési-száradási ciklusokkal modelleztük. A mintavételt követően, a behozatali állapotban történő felvételezés után, az első WDC nedvesítési szakaszaként a mintákat 30 l-es edényekbe állítottuk, majd óvatosan feltöltöttük vízzel az edényt és a mintákat három hétig telítettük. A PVC csöveket a 30 l-es mintavételi edényben rácsra állítottuk, hogy a telítődés egyrészt felülről, másrészt alulról is - a perforált kupakokon át - a kapillárisok szívóerejének megfelelően is végbemehessen, közelítve a belvízelöntésre leginkább jellemző természetes állapotot.

A WDC-k száradási szakaszában a mintákat nem tömegállandóságig, hanem egységesen nyolc napig hagytuk szobahőmérsékleten száradni, ezáltal vizsgálhatóvá vált a minták WDC-k hatására változó vízvisszatartási képessége is.

A száradási szakaszban a mintákat óvatosan kiemeltük a vízből, majd szintén rácsra állítottuk, hogy az oszlopban lévő víz az alsó, lyuggatott zárókupakon eltávozhasson és a természetes körülményeknek megfelelően a talajoszlopok tetején is párologhasson.

A CT-s felvételek készítését mindig a nyolc napos száradási szakaszt követően végeztük a négy hetes WDC-k lezárásaként. A harmadik ciklust követően a mintákat hat hónapig szobahőmérsékleten, majd 48 órán át $60^{\circ} \mathrm{C}$-on szárítószekrényben szárítottuk a száraz, kétfázisú talajállapot eléréséhez. 


\section{CT felvételek készitése, kiértékelése}

A talajoszlopok komputertomográfiás felvételezését a Kaposvári Egyetem Diagnosztikai és Onkoradiológiai Intézetében végeztük Siemens Somatom Sensation Cardiac típusú orvosi komputertomográffal ( $120 \mathrm{kV}, 250 \mathrm{mAs})$.

A roncsolásmentes vizsgálat érdekében a mintákról álló helyzetben készítettünk CT felvételeket (2. ábra). A $19 \mathrm{~cm}$ átméröjü talajoszlopokról 160 vertikális kép készült $(1,2 \mathrm{~mm}$-es szeletvastagság; $512 \times 512$ pixeles felvétel; 16 bites DICOM fájlként mentve; $880 \times 880 \mu \mathrm{m}^{2}$ pixelenkénti felbontásban). A felvételek kiértékelésekor a talajoszlopoknak csak a középső $120 \times 120 \mathrm{~mm}^{2}$ alapterületü hasábját elemeztük. Ezzel az eljárással a PVC cső által okozott falhatást, tömörödést próbáltuk kiküszöbölni - a PIRES és munkatársai (2004) által javasolt módszertan szerint.

A mérés során felülről lefelé haladva $5 \mathrm{~mm} \times 120 \mathrm{~mm}$-es vizsgálati egységeket (region of interest, ROI-kat) jelöltünk ki minden egyes vertikális képszeleten. Az $1,2 \mathrm{~mm}$-es szeletvastagságnak megfelelően $100 \mathrm{db}$ felvétel alkotja a $120 \times 120 \mathrm{~mm}^{2}$ alapterületủ hasábot, így $100 \mathrm{db}$ ROI található egymás mögött egy $5 \mathrm{~mm}$-es vizsgálati egységben (2. ábra). Minden egyes ROI háromdimenziós pixeléhez (voxeléhez) tartozik egy a $\mathrm{CT}$ által mért, a közeg sürüségével egyenes arányosságban álló Hounsfield-egység (HU).

A Hounsfield-skála standard nyomáson és hőmérsékleten a deszillált vízhez 0 HU értéket, a levegőhöz -1024 HU-t rendel. A skála pozitív végpontja (3000 HU) a teljes sugárelnyelésnek felel meg. A skála közbenső értékei a leképezendő közeg sugárgyengülési együtthatóinak lineáris összesítéséböl származtathatók (ROGASIK et al., 2003; GYARMATI, 2013).

A képfeldolgozás során meghatároztuk az általunk alkalmazott módszer szempontjából legkisebb, reprezentatív elemi térfogatot (REV). Ehhez a kijelölt ROI-k voxeleihez tartozó Hounsfield-értékeket átlagoltuk, majd egyszerü mozgó átlagolás során vizsgálatuk, hogy különböző számú, egymás mögötti ROI-k összevonásával hogyan változik az összevont egységek átlagolt HU-értékeinek relatív szórása.

A mozgó átlagolással összevont ROI-k számának és az így kapott relatív szórás értékeknek a függvényképén a reprezentatív térfogathoz tartozó összevonandó ROI darabszámot az a pont jelöli ki, ahol a függvénykép közel aszimptotikus lefutásúvá vált. $\mathrm{A}$ felvételek további kiértékelését az így megállapított reprezentatív térfogathoz tartozó HU-értékek elemzésével végeztük MS Office 2010, Syngo CT 2007S és Osiris 4.19 szoftvercsomagokkal.

Mivel a HU-értékek önmagukban nem tükröztek talajtani tulajdonságot, így ezeket átszámoltuk térfogattömeg értékekre. Az átszámoláshoz a ROGASIK és munkatársai (2003) és SCHRADER és munkatársai (2007) által is használt képleteket használtuk, melyek segítségével a talajminta fajsúlyának és aktuális relatív nedvességtartalmának ismeretében megadható a HU-értékhez tartozó térfogattömeg értékek $\left(\mathrm{g} \cdot \mathrm{cm}^{-3}\right)$. Az így származtatott térfogattömeg adatok statisztikai alapú kiértékelését normalitás vizsgálattal végeztünk (Kolmogorov-Smirnov teszt). Nem minden adatsor mutatott azonban normál eloszlást, ezért a nedvesedési-száradási ciklusok utáni térfogattömeg értékek közti különbséget nem paraméteres Wilcoxon-próbával teszteltük, IBM SPSS Statistics 22 programmal. 
A talajoszlopok szemléltetése céljából a CT felvételeket binárissá alakítottuk ArcMap 10 szoftverrel. A felvételek pixeleit a Hounsfield-értékek alapján sorba rendeztük, majd az egész talajoszlop összporozitás-értékével megegyező küszöbérték (\%) alapján fekete és fehér színkódolással láttuk el a képpontokat a nagyobb szerkezeti elemek kirajzolódása érdekében.

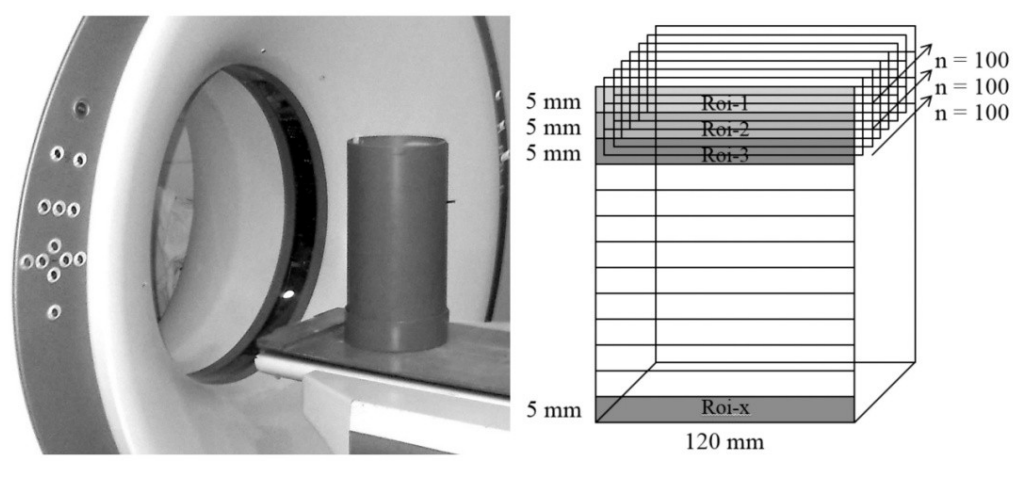

2. ábra

CT felvételek készítése a talajmintákról; a CT felvételek kiértékelése során alkalmazott, talajoszlopokon belül kijelölt vizsgálati elemek (ROI-k) helyzete

\section{Vizsgálati eredmények és értékelésük}

\section{A talajtani alapvizsgálatok eredményei}

A bolygatott talajminták alapvizsgálati adatai alapján a vizsgált talaj egy jó minöségü, közepesen humuszos, lefelé fokozatosan növekvő karbonáttartalmú, enyhén lúgos kémhatású csernozjom (1. táblázat).

\section{1. táblázat}

A talajminták alapvizsgálatainak eredményei

\begin{tabular}{|c|c|c|c|c|c|c|c|c|}
\hline $\begin{array}{c}(1) \\
\text { Minta- } \\
\text { mélység }\end{array}$ & $\begin{array}{c}\mathrm{pH} \\
\left(\mathrm{H}_{2} \mathrm{O}\right)\end{array}$ & $\begin{array}{c}(2) \\
\text { Összes } \\
\text { só }\end{array}$ & $\mathrm{CaCO}_{3}$ & $\begin{array}{c}(3) \\
\text { Humusz }\end{array}$ & $\begin{array}{c}(5) \\
\text { Agyag }\end{array}$ & $\begin{array}{c}(6) \\
\text { Iszap }\end{array}$ & $\begin{array}{c}(7) \\
\text { Homok }\end{array}$ & $\begin{array}{c}(4) \\
\text { Fajsúly }\end{array}$ \\
\hline $\mathrm{cm}$ & & \multicolumn{7}{|c|}{$\%$} \\
\hline $0-10$ & 7,93 & 0,02 & 9,06 & 2,97 & 8,6 & 53,3 & 38,1 & 2,39 \\
$10-20$ & 7,93 & 0,02 & 8,24 & 2,94 & 8,6 & 54,8 & 36,6 & 2,38 \\
$20-30$ & 7,90 & 0,03 & 9,89 & 3,05 & 9,2 & 55,4 & 35,4 & 2,38 \\
$30-40$ & 7,91 & 0,03 & 12,77 & 2,30 & 9,3 & 54,1 & 36,5 & 2,42 \\
$40-50$ & 8,01 & 0,04 & 18,54 & 1,57 & 10,0 & 53,3 & 36,8 & 2,38 \\
$50-60$ & 8,06 & 0,06 & 22,25 & 1,20 & 11,2 & 53,5 & 35,4 & 2,40 \\
\hline
\end{tabular}


A talaj fizikai félesége iszapos vályog textúra osztályba esett, bár az általunk alkalmazott lézeres szemcseanalízis az agyag frakció valós arányát alulbecsülhette (Di STEFANO et al., 2010; KUN et al., 2013).

A helyszíni vizsgálatok eredményei, mint pl. a mintavételkor tapasztalt morzsás szerkezet, a művelés okozta csekély eketalpréteg ellenére kedvező vízgazdálkodási tulajdonságra utaltak. A bolygatatlan talajminták WDC-k elött és után mért térfogat értékeit a CT felvételek alapján határoztuk meg (2. táblázat).

\section{2. táblázat}

A bolygatatlan talajminták (G1-G4) nedvesítési-száradási ciklusainak (WDC $\left.{ }_{1-3}\right)$ különböző nedvességi állapotában mért térfogatai $\left(\mathrm{cm}^{3}\right)$

\begin{tabular}{|c|c|c|c|c|c|}
\hline \multirow{2}{*}{$\begin{array}{l}\text { (1) } \\
\text { Minta }\end{array}$} & \multicolumn{5}{|c|}{$\begin{array}{c}\text { (2) } \\
\text { Térfogat }\end{array}$} \\
\hline & $\begin{array}{c}\text { (3) } \\
\text { Behozatali } \\
\text { állapotban }\end{array}$ & $\stackrel{(4)}{\mathrm{WDC}_{1} \text { után }}$ & $\stackrel{(5)}{\mathrm{WDC}_{2}}$ után & $\stackrel{(6)}{\mathrm{WDC}_{3}}$ után & $\begin{array}{l}\text { (7) } \\
\text { Szárítás után }\end{array}$ \\
\hline G1 & 9800,5 & 9783,0 & 9706,1 & 9725,0 & 9055,9 \\
\hline G2 & 9761,5 & 9807,3 & 9802,6 & 9802,0 & 9217,7 \\
\hline G3 & 10548,0 & 10581,0 & 10490,1 & 10473,6 & 9571,1 \\
\hline G4 & 9788,5 & 9930,0 & 9769,1 & 9866,6 & 9095,9 \\
\hline
\end{tabular}

$\mathrm{A} \mathrm{WDC}_{1}$-hez képest a $\mathrm{WDC}_{3}$ végén mind a négy párhuzamos minta térfogata csökkent, igazolva a nedvesítés-száradás által bekövetkezett talajszerkezet módosulást, a nagyobb szerkezeti elemek, aggregátumok feliszapolódás okozta szétesését. A három ciklust lezáró szárítás után a minták térfogata átlagosan 7,4\%-kal zsugorodott.

A CT felvételek alapján a négy talajoszlop egészére vonatkoztatott térfogattömegként behozatali állapotban átlagosan $1,42 \mathrm{~g} \cdot \mathrm{cm}^{-3}-\mathrm{t}$, szárított állapotban $1,54 \mathrm{~g} \cdot \mathrm{cm}^{-3}-\mathrm{t}$ mértünk. A térfogattömeg növekedése szoros összefüggésben áll a talajszerkezet tömörödésével, így a tapasztalt változás az ismételt nedvesítés és száradás szerkezettömörítő hatását igazolta a TISDALL és munkatársai (1978), valamint RAJARAM és ERBACH (1999) tanulmányaiban leírtakhoz hasonlóan.

A közel azonos összes porozitás értékek mellett ( $W_{D C}$ : átlagosan 40,78\%; $\mathrm{WDC}_{2}: 40,28 \%$; $\left.\mathrm{WDC}_{3}: 40,44 \%\right)$ a porozitás százalékában kifejezett, tömegmérésen alapuló relatív nedvességtartalom értékek nőttek a ciklusok során (72,8\%-ról 74,1\%-ra) (3. táblázat). Az ismételt WDC-k hatására egységnyi idő alatt a talajminták eltérő mértékben száradtak, így a talajoszlopok a ciklusok során egyre nagyobb nedvességtartalmat értek el - PIRES és munkatársainak (2007) eredményeihez hasonlóan.

A nagyobb relatív nedvességtartalom a rendelkezésre álló kisebb méretủ pórusok vízzel telítettségének nagyobb arányát jelzi a nagyobb méretű, levegővel telt pórusok arányával szemben. Feltételeztük, hogy a WDC-k során végbement szerkezetváltozás következtében a minták pórusméret-eloszlása is megváltozott. Ennek lehetőségét a későbbiekben a CT felvételek kiértékelésével vizsgáltuk. 


\section{3. táblázat}

A bolygatatlan talajminták nedvesítési-száradási ciklusainak különböző nedvességi állapotában mért, tömegmérésen alapuló relatív nedvességtartalom értékei (a porozitás \%-ában)

\begin{tabular}{|c|c|c|c|c|}
\hline \multirow{2}{*}{\begin{tabular}{c} 
Minta \\
\cline { 2 - 5 }
\end{tabular}} & \multicolumn{4}{|c|}{ Relatív nedvességtartalom (a porozitás \%-ában) } \\
\cline { 2 - 5 } & $\begin{array}{c}\text { (3) } \\
\text { Behozatali } \\
\text { állapotban }\end{array}$ & $\begin{array}{c}(4) \\
\mathrm{WDC}_{1} \text { után }\end{array}$ & $\begin{array}{c}(5) \\
\mathrm{WDC}_{2} \text { után }\end{array}$ & $\begin{array}{c}(6) \\
\mathrm{WDC}_{3} \text { után }\end{array}$ \\
\hline G1 & 60,7 & 73,8 & 72,2 & 74,0 \\
G2 & 61,0 & 70,1 & 67,6 & 70,6 \\
G3 & 56,3 & 69,2 & 71,0 & 72,2 \\
G4 & 65,4 & 78,1 & 79,3 & 79,5 \\
a) Átlag & 60,8 & 72,8 & 72,5 & 74,1 \\
\hline
\end{tabular}

\section{A nedvesitési-száradási ciklusok hatásának értékelése CT felvételek alapján}

A reprezentatív elemi térfogat megállapításánál a talajoszlopokban függőlegesen, 5 mm-enként kijelölt, egymás mögött összevonandó ROI-k számát határoztuk meg. Vizsgálatunkban $80 \mathrm{db}$ egymás mögötti ROI összevonásával kaptunk közel aszimptotikus függvényképet - a HU-értékek relatív szórása 0,01 volt. Egy ROI $5 \mathrm{~mm} \times 120 \mathrm{~mm} \times 1,2 \mathrm{~mm}$ térfogatú, így $80 \mathrm{db}$ ROI összevonásával $57600 \mathrm{~mm}^{3}$ térfogatot fogadtunk el reprezentatívnak. Ez a REV érték megfelel a BoRGES és PIRES (2012) által mért térfogatnak; Tapasztalataik szerint az $50-100 \mathrm{~cm}^{3}$ térfogatú, legalább $6,4 \mathrm{~cm}^{2}$ keresztmetszetű minták alkalmasak a talaj térfogattömegének reprezentatív vizsgálatára.

Az általunk gyüjtött 9-10 ezer $\mathrm{cm}^{3}$ térfogatú bolygatatlan minták jelentősen nagyobb térfogatúak, mint a vonatkozó szakirodalomban említett mintatérfogat (pl. Pedrotti et al., 2005; MoONEY \& MORRIs 2008; PIRES et al., 2008). Ez lehetőséget adott arra, hogy a falhatással terhelt mintarészeket - melyekről PIRES és munkatársai (2004) is beszámoltak - a CT felvételeken leválasszuk, és az általunk elfogadott $57,6 \mathrm{~cm}^{3}$-es REV egységek figyelembe vételével értékeljük a nedvesítési-száradási ciklusok során mért eredményeket, megfelelő mintaméret mellett. A WDC-k végén, a CT felvételek kiértékelése alapján megállapított térfogattömeg a talajoszlopok egészére vonatkoztatva kis mértékben változott (4. táblázat).

A talajmonolitok tömeg- és a minták CT-s térfogatmérésén alapuló relatív nedvességtartalmában mutatkozó különbségek már utaltak a WDC-k által okozott pórusméret-differenciálódásra. E pórusméret-változást igazolta a binárissá alakított CT felvételek kvalitatív vizsgálata is (4. ábra). A minták összporozitása közel változatlan maradt, de differenciált porozitásuk változott. $\mathrm{A} \mathrm{WDC}_{3}$ végén készült képeken a $\mathrm{WDC}_{1}$ állapothoz viszonyítva láthatóan kevesebb, a gravitációs pórusteret jelző, összefüggő fekete pixelcsoport rajzolódott ki, mely a nagyobb aggregátumok által közrefogott pórusok eltűnésére utal. 


\section{4. táblázat}

A talajoszlopok térfogattömeg értékei $\left(\mathrm{g} \cdot \mathrm{cm}^{-3}\right)$ az egyes nedvesítési-szaradási ciklusok $\left(W_{1-3}\right)$ után (az 5 mm-enként kijelölt reprezentatív térfogatú vizsgálati egységekben megállapított Hounsfield-értékek alapján)

\begin{tabular}{|c|c|c|c|c|}
\hline \multirow{3}{*}{$\begin{array}{c}(1) \\
\text { Minta }\end{array}$} & \multirow{2}{*}{\multicolumn{4}{|c|}{$\begin{array}{c}\text { (2) } \\
\text { Térfogattömeg }\end{array}$}} \\
\hline & & & & \\
\hline & $\begin{array}{l}\text { Statisztikai } \\
\text { mutató }\end{array}$ & $\mathrm{WDC}_{1}$ & $\mathrm{WDC}_{2}$ & $\mathrm{WDC}_{3}$ \\
\hline \multirow[t]{4}{*}{ G1 } & a) átlag & 1,44 & 1,45 & 1,45 \\
\hline & minimum & 1,37 & 1,37 & 1,37 \\
\hline & maximum & 1,51 & 1,52 & 1,52 \\
\hline & b) szórás & 0,04 & 0,04 & 0,04 \\
\hline \multirow[t]{4}{*}{ G2 } & a) átlag & 1,45 & 1,45 & 1,45 \\
\hline & minimum & 1,35 & 1,36 & 1,38 \\
\hline & maximum & 1,53 & 1,53 & 1,53 \\
\hline & b) szórás & 0,05 & 0,05 & 0,04 \\
\hline \multirow[t]{4}{*}{ G3 } & a) átlag & 1,34 & 1,35 & 1,35 \\
\hline & minimum & 1,24 & 1,24 & 1,25 \\
\hline & maximum & 1,50 & 1,51 & 1,51 \\
\hline & b) szórás & 0,08 & 0,08 & 0,08 \\
\hline \multirow[t]{4}{*}{ G4 } & a) átlag & 1,43 & 1,45 & 1,44 \\
\hline & minimum & 1,36 & 1,34 & 1,30 \\
\hline & maximum & 1,53 & 1,56 & 1,55 \\
\hline & b) szórás & 0,06 & 0,06 & 0,06 \\
\hline
\end{tabular}
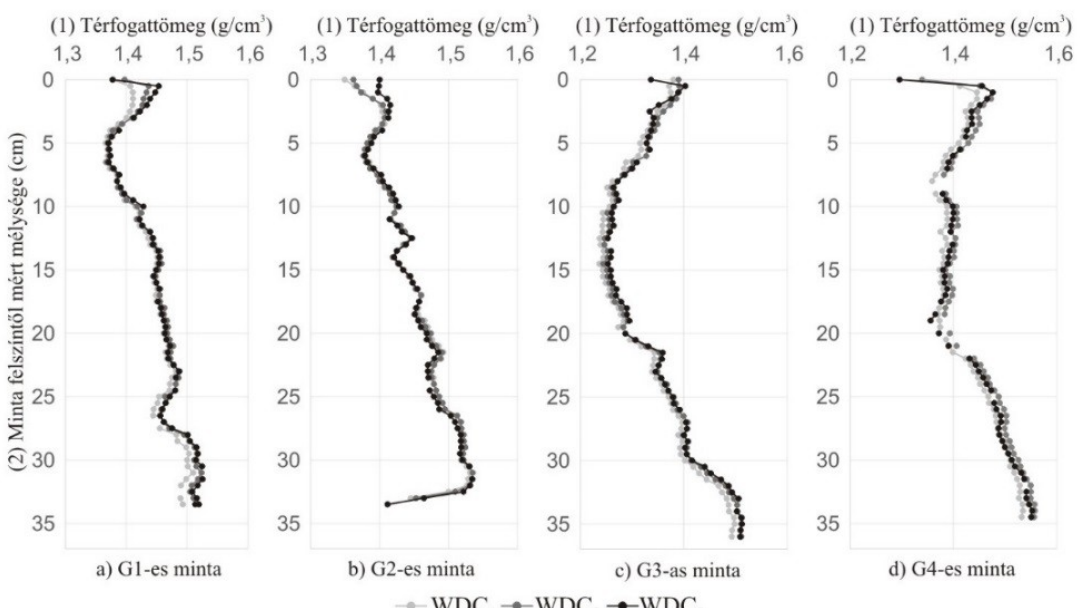

3. ábra

A talajoszlopokban 5 mm-enként kijelölt reprezentatív vizsgálati elemek térfogattömeg értékeinek vertikális változása az első, második és harmadik nedvesítési-száradási ciklusban

$\left(\mathrm{WDC}_{1-3}\right)$ 


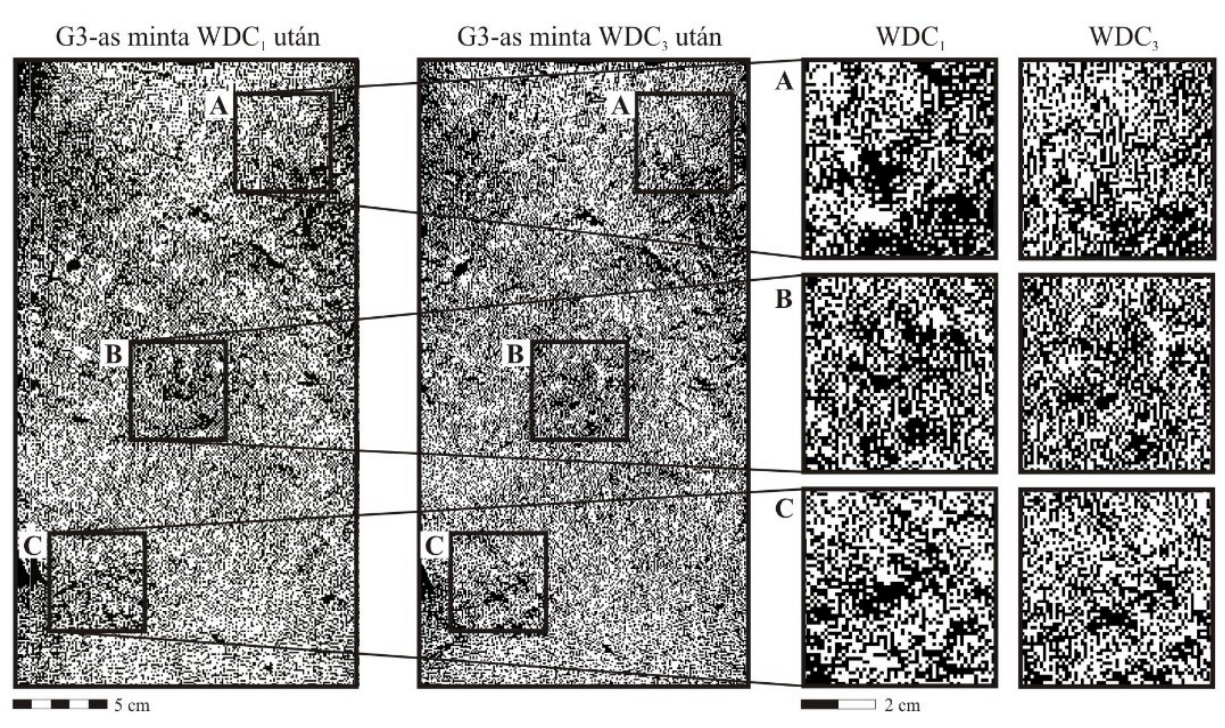

4. ábra

A G3-as minta első és harmadik nedvesítési-száradási ciklus $\left(\mathrm{WDC}_{1-3}\right)$ után készített, bináris komputertomográfiás felvételeinek összehasonlítása

A talajszerkezet homogenizálódását - a HILLEL (2004), ill. RASA és munkatársai (2012) tanulmányaiban leírtaknak megfelelően - a szerkezeti elemek szétesése, feliszapolódása okozhatta, melynek során a nagyobb pórusokat, hézagokat a kisebb szerkezeti elemek, talajszemcsék kitöltötték.

PIRES és munkatársai (2008) kis térfogatú $\left(50 \mathrm{~cm}^{3}\right)$, szerkezetileg leromlott talajokon végzett vizsgálatuk során a WDC-k hatásaként térfogattömeg csökkenést, szerkezet javulást tapasztaltak. Kutatásunk tapasztalatai szerint azonban, az eredendően jó minőségű talajok esetében, az ismétlődő nedvesedési-száradási ciklusok nemhogy térfogattömeg csökkenést, de tömörödést, talajszerkezeti degradációt váltanak ki, amelyek kedvezőtlenebb levegö- és vízgazdálkodási tulajdonságokat kialakítva a későbbiekben továbbnövelhetik a belvízzel érintett területek belvízveszélyeztetettségét.

\section{Összefoglalás}

Kutatásunk során a belvíz talajszerkezetre gyakorolt hatását modelleztük háromszor ismételt nedvesítési-száradási ciklussal (WDC) négy darab, közel 10 ezer $\mathrm{cm}^{3}$ térfogatú, bolygatatlan talajmintán.

A talajszerkezet változását vizsgáltuk komputertomográffal (CT), annak érdekében, hogy 1) a minták belső szerkezeti viszonyait láthatóvá tegyük, 2) a mintavételezéssel járó, zavaró falhatást kiküszöbölhessük és 3) a nedvesítési-száradási ciklusok után összehasonlító elemzést végezhessünk. 
A három nedvesedési-száradási ciklusból álló kísérlet során az eredendően talajhibától mentes, jó vízgazdálkodású, jó minőségű talajmintákat $880 \times 880 \mu \mathrm{m}^{2}$ pixel felbontásban felvételeztük komputertomográffal. Meghatároztuk a vizsgálat szempontjából reprezentatív elemi térfogatot, majd a talajoszlopokat e térfogati elemekre osztva elemeztük tovább. A CT-vel mért, sürüséget jelző Hounsfield-egységeket átszámoltuk száraz térfogattömeg értékekre.

A kísérlet eredményeként a bolygatatlan minták kismértékű térfogattömeg növekedését, valamint a nagyobb méretü pórusok arányának csökkenését figyeltük meg. Ezáltal igazoltuk, hogy talajmüvelési beavatkozás nélkül, a belvíz okozta tartós vízborítás alatt álló talajok szerkezeti degradációja a későbbiekben tovább növelheti a területen a belvízkockázatot.

A kutatás a TÁMOP 4.2.4.A/2-11-1-2012-0001 azonosító számú Nemzeti Kiválóság Program - Hazai hallgatói, illetve kutatói személyi támogatást biztosító rendszer kidolgozása és müködtetése országos program címü kiemelt projekt által nyújtott személyi támogatással valósult meg. A projekt az Európai Unió támogatásával, az Európai Szociális Alap társfinanszírozásával valósul meg.

Kulcsszavak: talajszerkezet, belvíz, nedvesedési-száradási ciklusok, komputertomográfia

\section{Irodalom}

Anderson, S. H., Peyton, R. L. \& Gantzer, C. J., 1990. Evaluation of constructed and natural soil macropores using X-ray computed Tomography. Geoderma. 46. 1329.

Barna, Gy., Dunai, A., Makó, A., Tóth, Z., Barton, G. \& Lamorski, K., 2013. Comparative analysis of the organic liquid conductivity of soil samples treated with cationic surfactant. Georgikon for Agriculture. 18. 41-55.

Borges, J. A. R. \& PIRES, L. F., 2012. Representative elementary area (REA) in soil bulk density measurements through gamma ray computed tomography. Soil \& Tillage Research. 123. 43-49.

BuZÁs I. (szerk.), 1988. Talaj- és agrokémiai vizsgálati módszerkönyv 2. A talajok fizikai-kémiai és kémiai vizsgálati módszerei. Mezőgazdasági Könyvkiadó Vállalat. Budapest.

Crestana, S. \& VAZ, C. M. P., 1998. Non-invasive instrumentation opportunities for characterising soil porous system. Soil \& Tillage Research. 47. 19-26.

Crestana, S., Mascarenhas, S. \& Pozzi-Mucelli, R. S., 1985. Static and dynamic 3 dimensional studies of water in soil using computed tomographic scanning. Soil Science. 140. 326-332.

Di Stefano, C., Ferro, V. \& Mirabile, S., 2010. Comparison between grain-size analyses using laser diffraction and sedimentation methods. Biosystems Engineering 106. 205-215. 
GÁL N. \& FARSANG A., 2012. Belvízi elöntés hatása a talajminőségre, különös tekintettel a talajszerkezeti változásokra. In: Sokarcú Klímaváltozás. (Szerk.: RAKONCZAI, J., LADÁNYI, Zs. \& PÁL-Molnár, E.) 77-89. GeoLitera. Szeged.

GÁL, N. \& FARSANG, A., 2013. Weather extremities and soil processes: Impact of excess water on soil structure in the Southern Great Hungarian Plain. In: Geomorphological Impacts of Extreme Weather: Case Studies from Central and Eastern Europe. (Ed.: Lóczy, D.) 313-325. Springer Science+Business Media. Dordrecht.

Gantzer, C. J. \& Anderson, S. H., 2002. Computed tomographic measurement of macroporosity in chisel-disk and no-tillage seedbeds. Soil \& Tillage Research. 64. (1-2) 101-111.

GyARMATI B., 2013. Gázdiffúzió modellezése bolygatatlan talajoszlopokban a talajszerkezet függvényében. PhD értekezés, Szent István Egyetem. Gödöllő

Hainsworth, J. M. \& Aylmore, L. A. G., 1983. The use of computer-assisted tomography to determine spatial distribution of sol water content. Australian Journal of Soil Research. 21. 435-443.

HILlel, D., 2004. Introduction to environmental soil physics. Elsevier Academic Press. New York.

Jégou, D., Brunotte, J., Rogasik, H., Capowiez, Y., Diestel, H., Schrader, S. \& CluZEAU, D., 2002. Impact of soil compaction on earthworm burrow systems using X-ray computed tomography: preliminary study. European Journal of Soil Biology. 38. 329-336.

Kun, Á., Katona, O., Sipos, Gy. \& BARTA., K., 2013. Comparison of pipette and laser diffraction methods in determining the granulometric content of fluvial sediment samples. Journal of Environmental Geography, 6. (3-4) 49-54.

LANGmaAck, M., Schrader, S., RAPP-BernhardT, U. \& Kotzke, K., 1999. Quantitative analysis of earthwormburrow systems with respect to biological soil-structure regeneration after soil compaction. Biology and Fertility of Soils. 28. 219-229.

LiPIEC, J. \& HATANO, R., 2003. Quantification of compaction effects on soil physical properties and crop growth. Geoderma. 116. 107-136.

MikiTA V., 2013. Tomográfiás képdiagnosztikai vizsgálatok hidro- és mérnökgeológiai célú alkalmazási lehetőségei. PhD értekezés. Miskolci Egyetem. Miskolc

MoOnEy, S. J. \& MoRRIS, C., 2008. A morphological approach to understand preferential flow using image analysis with dye tracers and X-ray Computed Tomography. Catena. 73. 204-211.

Pedrotti, A., Pauletto, E. A., Crestana, S., Holanda, F. S. R., Cruvinel, P. E. \& VAZ, C. M. P., 2005. Evaulation of bulk density of Albaqualf soil under different tillage systems using the volumetric ring and computerized tomography methods. Soil \& Tillage Research. 80. 115-123.

Peth, S., Nellesen, J., Fischer, G. \& Horn, R., 2010. Non-invasive 3D analysis of local soil deformation under mechanical and hydraulic stresses by $\mu \mathrm{CT}$ and digital image correlation. Soil \& Tillage Research 111. 3-18.

Petrovic, A. M., Siebert, J. E. \& Rieke, P. E., 1982. Soil bulk density analysis in three dimensions by computed tomographic scanning. Soil Science Society of America Journal. 46. 445-450. 
Pires, L. F., De Macedo, J. R., De Souza, M. D., Bacchi, O. O. S. \& Reichardt, K., 2003. Gamma-ray-computed tomography to investigate compaction on sewagesludge-treated soil. Applied Radiation and Isotopes 59. (1) 17-25.

Pires, L. F., BACChi, O. O. S. \& ReichardT, K., 2004. Damage to soil physical properties caused by soil sampler devices as assessed by gamma ray computed tomography. Australian Journal of Soil Research. 42. 857-863.

Pires, L. F., BACCHI, O. O. S. \& ReICHARDT, K., 2007. Assessment of soil structure repair due to wetting and drying cycles through $2 \mathrm{D}$ tomographic image analysis. Soil \& Tillage Research. 94. 537-545.

Pires, L. F., Cooper, M., Cássaro, F. A. M., Reichardt, K., Bacchi, O. O. S. \& Dias, N. M. P., 2008. Micromorphological analysis to characterize structure modifications of soil samples submitted to wetting and drying cycles. Catena. 72. 297-304.

Pires, L. F., Borges, J. A. R, Bacchi, O. O. S. \& Reichardt, K., 2010. Twenty-five years of computed tomography in soil physics: A literature review of the Brazilian contribution. Soil \& Tillage Research. 110. 197-210.

RAJARAM, G. \& ERBACH, D. C., 1999. Effect of wetting and drying on soil physical properties. Journal of Terramechanics. 36. 39-49.

RAsa, K., EICKHORSt, T., TIPPKÖTteR, R. \& Yli-Halla, M., 2012. Structure and pore system in differently managed clayey surface soil as described by micromorphology and image analysis. Geoderma. 173-174. 10-18.

RICHARDSON, S. J., 1976. Effect of artificial weathering cycles on the structural stability of a dispersed silt soil. Journal of Soil Science. 27. 287-94.

Rogasik, H., Onasch, I., Brunotte, J., JÉgou, D. \& Wendroth, O., 2003. Assessment of soil structure using X-ray tomography. In: Applications of X-ray Computed Tomography in Geosciences. (Eds.: MeEs, F., Swennen, R., VAn GeEt, M. \& JaCOBS, P.) Special Publications. 215. 151-165. Geological Society. London.

Sander, T., Gerke, H. H. \& Rogasik, H., 2008. Assessment of Chinese paddy-soil structure using X-ray computed tomography. Geoderma. 145. 303-314.

SCHRADER, S., ROGASIK, H., ONASCH, I. \& JÉGOU, D., 2007. Assessment of soil structural differentiation around earthworm burrows by means of X-ray computed tomography and scanning electron microscopy. Geoderma. 137. 378-387.

Tisdall, J. M., CockCraft, B. \& Uren, N. C., 1978. The stability of soil aggregates as affected by organic materials, microbial activity and physical disruption. Australian Journal of Soil Research. 16. (1) 9-17.

VÁrallyay Gy., 2005. A talaj és a víz. In: A talajok jelentősége a 21. században. (Szerk.: StefAnOPVITS P. \& MichÉli E.) 61-76. MTA Társadalomkutató Központ. Budapest.

ZINK, A., Fleige, H. \& HORN, R., 2011. Verification of harmful subsoil compaction in loess soils. Soil \& Tillage Research. 114. 127-134.

Érkezett: 2015. február 15. 


\title{
Investigation of the effects of water inundation on the soil structure using computed tomography
}

\author{
${ }^{1}$ N. GÁL, ${ }^{2}$ T. M. TÓTH, ${ }^{3}$ T. FÖLDES and ${ }^{1}$ A. FARSANG
}

${ }^{1}$ Department of Physical Geography and Geoinformatics, ${ }^{2}$ Department of Mineralogy, Geochemistry and Petrology, University of Szeged, Szeged and ${ }^{3}$ Institute of Diagnostic Imaging and Radiation Oncology, University of Kaposvár, Kaposvár

\section{Summary}

Soil structure is a dynamic property, which is influenced by numerous human and natural processes, and by mechanical and hydraulic stress factors. One of the hydraulic stress factors is inundation by inland excess water (IEW), which strengthens the effect of wetting and drying cycles (WDCs) during the prolonged, 2-3-month water inundation periods. Despite numerous studies, there are few reports about the effects of temporary water inundation on the structure of undisturbed soil samples, collected in a larger volume and measured using computed tomography (CT) techniques.

The objective of this study was therefore to evaluate the effect on the soil structure of repeated water inundation caused by IEW. For this purpose, undisturbed soil samples with a volume of approx. $10000 \mathrm{~cm}^{3}$ were collected in PVC cylinders (with four replicates) on a sampling area characterised by a healthy, well-structured chernozem soil with favourable water management. A model experiment was set up with three WDCs, for each of which the soil samples were saturated with water for three weeks and then dried at room temperature for a week. After each WDC, the soil samples were scanned with a SIEMENS Somatom Sensation Cardiac medical X-ray CT scanner with a voxel resolution of $880 \times 880 \times 1200 \mu^{3}$. After defining the representative elementary volume (REV), the structural modification along the soil columns was investigated by converting the Hounsfield tomographic units to dry bulk density values.

A slight increase in the bulk density values and a reduction in the ratio of largersized pores were detected in the intact soil cores after the WDCs. It was thus proved that, without soil tillage operations, the structural soil degradation caused by repeated water inundation in originally well-structured soils with initially favourable water management could trigger the risk of further IEW formation.

Table 1. Basic soil properties of disturbed soil samples. (1) Sampling depth, cm. (2) Total salt content, \%. (3) Humus content, \%. (4) Particle density, $\mathrm{g} \cdot \mathrm{cm}^{-3}$. (5) Clay content, \%. (6) Silt content, \%. (7) Sand content, \%.

Table 2. Volume $\left(\mathrm{cm}^{3}\right)$ of intact soil cores (G1-G4) after the wetting and drying cycles (WDCs). (1) Soil sample. (2) Volume $\left(\mathrm{cm}^{3}\right)$. (3) Initial state after sampling. (4) After $W_{1} C_{1}$. (5) After $W_{2}$. (6) After $W^{2} C_{3}$. (7) After drying.

Table 3. Relative moisture content (as a \% of total porosity) of intact soil cores after the wetting and drying cycles (WDCs). (1) Soil sample. (2) Relative moisture content (as a $\%$ of total porosity). (3) Initial state after sampling. (4) After $\mathrm{WDC}_{1}$. (5) After $\mathrm{WDC}_{2}$. (6) After $\mathrm{WDC}_{3}$. a) Mean.

Table 4. Dry bulk density values $\left(\mathrm{g} \cdot \mathrm{cm}^{-3}\right)$ of the soil cores after the wetting and drying cycles (WDCs), (calculated from the Hounsfield units measured at $5 \mathrm{~mm}$ depths 
along the soil columns). (1) Soil sample. (2) Dry bulk density $\left(\mathrm{g} \cdot \mathrm{cm}^{-3}\right)$. a) Mean, b) Standard deviation.

Figure 1. Interactions between soil and water inundation caused by inland excess water. (1) Global climate change. (2) Increase in the frequency of extreme weather events. (3) Increase in inland excess water inundation. (4) Permanent water inundation. (5) Soil structural degradation. a) Soaking, b) Decrease in aggregate stability, c) Crusting, d) Soil compaction, e) Compacted soil structure, f) High proportion of silt fraction, g) High bulk density, low porosity, h) Limited drainage, i) Low water storage capacity, j) Decreasing infiltration.

Figure 2. Scanning of the soil cores; location of the regions of interest (ROIs) along the CT slices.

Figure 3. Vertical profile of the dry bulk density values $\left(\mathrm{g} \cdot \mathrm{cm}^{-3}\right)$ along the soil columns (G1-G4) after the wetting and drying cycles (WDCs). (1) Bulk density, $\mathrm{g} \cdot \mathrm{cm}^{-3}$. (2) Depth from surface, cm. a) Soil sample G1, b) Soil sample G2, c) Soil sample G3, d) Soil sample G4.

Figure 4. Comparison of $\mathrm{CT}$ images of sample $\mathrm{G} 3$ after the first and third wetting and drying cycles $\left(\mathrm{WDC}_{1-3}\right)$. 
